detailed recommendations as to the manner in which education can foster the acquisition of these qualities; with regard to children in schools it suggests that particular attention should be paid to relating the subjects of study to circumstances and events outside school and to providing opportunities for the exercise of responsibility. Reference is made also to adult education, to plans for mass education, and to the possibility of extending work in adult education through movements such as the Workers' Educational Association and University extension schemes in England. The importance of the cinema, wireless, the Press, and government information services are noted. The report is insistent on the need for educational work to be accompanied by advances in political responsibility, and attaches special importance to the development of local government and to the participation of Africans in development councils and the co-operative movement.

\title{
Memorial to Lord Lugard
}

THE Executive Council of the Institute, at its recent meeting in Brussels, approved a proposal from the Bureau that Lord Lugard, its first chairman, should be commemorated by the institution of a lecture, to be known as the Lugard Memorial Lecture, and to be delivered annually, if possible, on the occasion of the meeting of the Executive Council. An invitation to deliver the lecture shall be regarded as an award for meritorious work in the field of African studies.

Each lecturer will receive an honorarium of twenty guineas, or books of an equivalent value; the lecture, unless the Executive Council shall determine otherwise, will be delivered in either English or French and will be published in Africa, or in such other form as the Executive Council may tecommend.

\section{Inquiry into the Effect of Modern Contacts upon the African Family with Special Reference to Marriage Laws and Customs}

A MAJOR research project, for the expenses of which grants have been awarded by the Carnegie Corporation of New York and the British Colonial Office, is to be carried out under the joint auspices of the Institute and the International Missionary Council. The subject of the inquiry is one which is arousing increasing interest in scientific, missionary, and administrative circles, and its importance for an understanding of the present situation in Africa, and for the solution of many sociological, religious, and administrative problems, will not be questioned.

The inquiry, as planned, will be carried out in two stages. The first stage will be concerned with a survey of the very considerable body of scattered and largely unco-ordinated material already available in published and other documentary sources, and with the preparation of a report which will be of immediate value to those directly concerned with the practical aspects of these questions. As a result of this survey it will be possible to delimit the special aspects of the study and the specific areas in which further researches will be required. It is hoped that field studies in selected areas will constitute the second stage of the inquiry.

The inquiry will be directed by a committee appointed jointly by the International African Institute and the International Missionary Council, and including representatives of the Colonial Social Science Research Council, the Conférence Romaine des Missions en Afrique, the Association of Social Anthropologists, and other interested bodies.

\section{Centre Local de l'Institut Frangais d'Afrique Noire au Dahomey}

$L_{E}$ Centre local de l'Institut Français d'Afrique Noire au Dahomey a été créé en 1942, mais n'a commencé à s'organiser qu'à la fin de 1944 . Son activité s'est orientée tout naturelle- 